\title{
Apomorfina w zaawansowanej chorobie Parkinsona
}

\section{Apomorphine in advanced Parkinson disease}

\author{
Andrzej Bogucki \\ Klinika Chorób Układu Pozapiramidowego, Uniwersytet Medyczny w Lodzi
}

Neurologia i Neurochirurgia Polska 2013; 47, 5: 476-483

DOI: 10.5114/ninp.2013.38227

\section{Streszczenie}

Apomorfina jest najsilniejszym agonistą dopaminergicznym, o skuteczności porównywalnej z lewodopą. Po podskórnym podaniu wchłania się szybko i całkowicie. Maksymalne stężenie w surowicy osiąga po 5-15 minutach, a efekt kliniczny ujawnia się po 20 minutach. Pojedyncze podskórne wstrzyknięcia apomorfiny są skuteczne jako leczenie doraźne przerywające nieprzewidywalne stany off w zaawansowanej chorobie Parkinsona. Obecnie apomorfina częściej stosowana jest w postaci ciągłych wlewów podskórnych, co zapewnia ciągłą stymulację dopaminergiczną. Wyniki badań zgodnie wskazują na skuteczność tej terapii w odniesieniu do stanów off, jednak są mniej jednoznaczne w przypadku dyskinez. Dwie terapie infuzyjne (apomorfina i dojelitowa lewodopa) oraz głęboka stymulacja mózgu są skuteczne w zaawansowanej chorobie Parkinsona $z$ opornymi komplikacjami ruchowymi. Wlewy apomorfiny powinny być brane pod uwagę u chorych, u których zastosowanie głębokiej stymulacji mózgu nie jest możliwe ze względu na zaburzenia funkcji poznawczych i przeciwwskazania neurochirurgiczne.

Słowa kluczowe: apomorfina, zaawansowana choroba Parkinsona, powikłania ruchowe, ciagła stymulacja dopaminergiczna.

\section{Wstęp}

Apomorfina to najdłużej znany agonista dopaminergiczny [1] i dotąd jedyny lek z tej grupy, którego skuteczność w odniesieniu do objawów ruchowych cho-

\begin{abstract}
Apomorphine is the most potent dopamine receptor agonist and its symptomatic effectiveness is comparable to levodopa. Subcutaneous apomorphine is rapidly and completely absorbed. Plasma peak concentrations are achieved after 5-15 minutes and onset of clinical effect is within 20 minutes. Apomorphine intermittent subcutaneous injections are effective as rescue therapy for unpredictable off periods in advanced Parkinson disease (PD). More often apomorphine is administered as a subcutaneous infusion which secures the continuous dopaminergic stimulation. The benefit on 'off' periods is consistent across all studies, but dyskinesia improvement is not so obvious. Two infusion therapies (apomorphine and intraduodenal levodopa) and deep brain stimulation (DBS) are effective in advanced PD patients with untreatable motor complications. Apomorphine infusions should be considered in patients unable to undergo DBS because of cognitive impairment and neurosurgical contraindications.
\end{abstract}

Key words: apomorphine, advanced Parkinson disease, motor complications, continuous dopaminergic stimulation.

roby Parkinsona jest porównywalna $\mathrm{z}$ efektem terapeutycznym lewodopy.

Apomorfina jest nienarkotyczną pochodną morfiny, która osiąga ośrodkowy układ nerwowy bez udziału aktywnego transportu. Wykazuje dziesięciokrotnie więk-

Adres do korespondencii: prof. dr hab. Andrzej Bogucki, Klinika Chorób Układu Pozapiramidowego, Uniwersytet Medyczny w Łodzi, III Szpital Miejski im. dr. Karola Jonschera, ul. Milionowa 14,93-113 Łódź, Polska, e-mail: andrzej.bogucki@umed.lodz.pl

Prace otrzymano: 19.03.2013; przyięto do druku: 23.08.2013 
sze niż dopamina powinowactwo do receptorów $\mathrm{D}_{1} \mathrm{i} \mathrm{D}_{2}$ oraz pięciokrotnie większe do receptorów $\mathrm{D}_{3}$. Wiąże się zarówno z receptorami pre-, jak i postsynaptycznymi. Bardzo dobrze wchłania się z przewodu pokarmowego, jednak jej biodostępność przy podaniu doustnym jest bardzo mała ze względu na efekt pierwszego przejścia przez wątrobę [2]. Podana we wstrzyknięciu podskórnym maksymalne stężenie w osoczu osiąga po 515 minutach, a w płynie mózgowo-rdzeniowym po 1525 minutach $[3,4]$. Efekt kliniczny ujawnia się po upływie 3-35 (najczęściej 5-20) minut od wstrzyknięcia i utrzymuje przez 30-120 (zazwyczaj ponad 45) minut [1,5,6].

Ze względu na szczególne cechy farmakokinetyki apomorfiny i brak możliwości stosowania jej w postaci doustnej podejmowano próby podawania leku innymi drogami, które mogłyby znaleźć zastosowanie w praktyce klinicznej. Skuteczność (w tym czas oczekiwania na efekt kliniczny i jego długość) w przypadku zastosowania apomorfiny w postaci sprayu donosowego była bardzo zbliżona do obserwowanej przy iniekcjach podskórnych. Niestety, większość pacjentów po podaniu leku zgłaszała uczucie zatkania nosa i pieczenie spowodowane podrażnieniem śluzówki, a u niektórych chorych rozwijał się stan zapalny przedsionka nosa [7-9].

Apomorfina podana podjęzykowo wykazuje podobną skuteczność jak we wstrzyknięciu; istotnym problemem w wypadku tej drogi podania leku jest jego nieprzyjemny smak oraz częste zapalenie dziąseł [10-12]. Zbliżony efekt terapeutyczny można również uzyskać, podając apomorfinę doodbytniczo $[13,14]$.

Ostatnio przedstawiono wyniki badania prowadzonego metodą podwójnie ślepej próby, z grupą kontrolną otrzymującą placebo, oceniającego skuteczność apomorfiny stosowanej w postaci proszku do inhalacji. Po podaniu tą drogą lek osiąga maksymalne stężenie w osoczu już po 1-3 minutach, jednak - w zastosowanych dawkach - okazał się nieskuteczny w przerywaniu stanów off [15].

\section{Podskórne wstrzyknięcia apomorfiny}

Przedstawione właściwości farmakokinetyczne apomorfiny sprawiły, że iniekcje podskórne w codziennej praktyce klinicznej znalazły zastosowanie w doraźnym leczeniu (rescue therapy) przerywającym stany off.

Badania z grupą kontrolną wykazały, że pojedyncze wstrzyknięcia apomorfiny skutecznie (w $95 \pm 2,4 \%$ przypadków podania leku) [2] przerywały stany off, a wykonywane kilkakrotnie w ciągu dnia znamiennie skracały łączny czas trwania stanów off (różnice znamienne w porównaniu z placebo). Efekt uzyskiwany po podaniu apomorfiny był porównywalny z obserwowanym u tych samych pacjentów po zastosowaniu lewodopy [16]. U osób, którym podawano apomorfinę, wynik w skali Unified Parkinson's Disease Rating Scale (UPDRS) był znamiennie niższy po 10, 20 i 60 minutach od iniekcji $[17,18]$, a według jednego z badań nawet po upływie 90 minut od podania leku [19]. Przy większych dawkach uzyskiwano dłużej utrzymujący się efekt terapeutyczny [19]. Wielokrotnie powtarzane wstrzyknięcia apomorfiny istotnie zmniejszały nasilenie objawów w stanie off [20].

Wyniki kilku badań konsekwentnie wykazywały czas oczekiwania na działanie leku wynoszący 5-15 minut i efekt terapeutyczny utrzymujący się przez 20-120 minut [21-25]. Uzyskiwano skrócenie łącznego czasu off o 3,1-4 godziny $[22,24,25]$ lub 41-55\%, gdy wynik podawany był w wartościach względnych $[21,23]$.

Badanie oceniające skuteczność stopniowo zwiększanych dawek leku wykazało, że wraz ze zwiększaniem dawki uzyskiwano większą i dłużej trwającą poprawę, ale jednocześnie wzrastało ryzyko wystąpienia objawów niepożądanych. Przy uwzględnieniu obu tych elementów optymalne w przypadku większości pacjentów były dawki wynoszące 4-6 mg [19].

$\mathrm{Na}$ efekt terapeutyczny uzyskany po podskórnym podaniu apomorfiny w bolusie wpływa stopień zaawansowania choroby. W przypadku pacjentów z fluktuacjami wearing off oraz chorych $\mathrm{z}$ nieprzewidywalnymi fluktuacjami i dyskinezami pląsawiczymi obserwowano krótszy czas poprawy i zwężenie okna terapeutycznego (ujawnianie się dyskinez szczytu dawki przy mniejszych dawkach leku), przy podobnej wielkości dawki progowej i dawki optymalnej [26].

W badaniach z grupą kontrolną otrzymująca placebo do najczęściej obserwowanych objawów niepożądanych u pacjentów leczonych podskórnymi iniekcjami apomorfiny należały ziewanie, senność, nieukładowe zawroty głowy i nudności $[17,27]$. Częstość występowania skutków ubocznych zwiększa się wraz z dawką leku podaną we wstrzyknięciu [19]. Włączenie iniekcji apomorfiny do terapii nie powoduje u pacjentów pogłębienia się niedociśnienia ortostatycznego [19]. Na podstawie wieku pacjenta, tolerancji wcześniej stosowanych leków dopaminergicznych i występowania hipotonii ortostatycznej w przeszłości nie można ocenić prawdopodobieństwa wystąpienia wczesnych objawów niepożądanych po podaniu apomorfiny ani jej długoterminowej tolerancji [28]. 
Pacjent zakwalifikowany do leczenia podskórnymi wstrzyknięciami apomorfiny powinien przejść procedurę, której celem z jednej strony jest ustalenie optymalnej dawki, a z drugiej - ocena tolerancji leku. Poniższe zasady postępowania zalecane są w Wielkiej Brytanii [29] (producenci leku mogą zalecać procedury różniące się pewnymi szczegółami od postępowania przedstawionego poniżej):

1. Przez 72 godz. przed pierwszym wstrzyknięciem apomorfiny pacjent powinien zaczać przyjmować domperydon w dawce $3 \times 20 \mathrm{mg} /$ dobę (domperydon jest obwodowym antagonistą receptorów dopaminergicznych i pozwala zapobiec nudnościom i wymiotom oraz spadkom ciśnienia krwi spowodowanym przez apomorfinę).

2. Należy odstawić wszystkie leki przeciwparkinsonowskie na 4-6 godz. przed podaniem pierwszej dawki apomorfiny (może to spowodować znaczne ograniczenie sprawności ruchowej pacjenta i uniemożliwić dotarcie do lekarza mającego przeprowadzić test, dlatego optymalnym rozwiązaniem jest 1-2-dniowa hospitalizacja).

3. Należy (1) ocenić stan motoryczny chorego, korzystając z III części skali UPDRS, oraz (2) zmierzyć czas, w którym chory w stanie off pokonuje dystans $12 \mathrm{~m}$ (te dane wyjściowe będą stanowiły odniesienie dla wyników tych samych testów powtarzanych po podaniu kolejnych dawek apomorfiny).

4. Należy podać $1 \mathrm{mg}$ apomorfiny podskórnie i obserwować pacjenta przez $30 \mathrm{~min}$; przedmiotem oceny jest zarówno nasilenie objawów parkinsonowskich, jak i obecność ewentualnych objawów ubocznych.

5. W razie braku lub niewielkiej poprawy po $30 \mathrm{~min}$ należy podać $3 \mathrm{mg}$ apomorfiny i ponownie ocenić stan chorego po $30 \mathrm{~min}$.

6. Przy braku efektu należy, również w odstępach 30-minutowych, podać dawkę $5 \mathrm{mg}$ i $7 \mathrm{mg}$. Przy braku jakiejkolwiek reakcji na dawkę $7 \mathrm{mg}$ pacjent powinien zostać uznany za niereagującego na apomorfinę. Jeśli zaobserwowano słabą odpowiedź po podaniu $7 \mathrm{mg}$, to w na stępnej iniekcji można podać maksymalną dawkę jednorazową, tj. $10 \mathrm{mg}$.

Indywidualnie ustalona optymalna dawka apomorfiny pozostaje skuteczna przez dłuższy czas i rzadko zachodzi potrzeba jej zwiększania [14]. Domperydon powinien być podawany co najmniej przez pierwsze 2 miesiące terapii, później zwykle możliwe jest jego stopniowe odstawienie [2].

Podskórne wstrzyknięcia apomorfiny mogą być szczególnie skuteczne u chorych z powoli narastającymi fluktuacjami ruchowymi wearing off oraz w przypadkach, gdy objawy pozaruchowe zapowiadają wystąpienie stanu off i pogorszenia stanu ruchowego pacjenta. Dobrymi kandydatami do leczenia apomorfiną podawaną w bolusach są też chorzy ze stanami ciężkiej akinezji występującymi rano po przebudzeniu [17].

\section{Ciqgły podskórny wlew apomorfiny}

Zaawansowane stadium choroby Parkinsona charakteryzuje się występowaniem komplikacji ruchowych, czyli fluktuacji i dyskinez. Stopniowemu zwężeniu ulega tzw. okno terapeutyczne, czyli coraz trudniej - pomimo indywidualnego dostosowywania liczby i wysokości dawek leków doustnych - uzyskać stan on bez dyskinez. Nie ma wątpliwości, że główną przyczyną fluktuacji i dyskinez jest postęp samej choroby. Jednak za czynnik w znacznym stopniu współodpowiedzialny za wystąpienie komplikacji ruchowych uważa się niefizjologiczne, pulsacyjne stymulowanie receptorów dopaminowych prążkowia przez leki stosowane w chorobie Parkinsona. Pulsacyjna stymulacja powoduje dysregulację na poziomie białek wewnątrzkomórkowych, co w efekcie prowadzi do znacznych wahań częstotliwości wyładowań neuronów prążkowia i dysregulacji struktur przez nie kontrolowanych. Za taki stan w znacznie większym stopniu jest odpowiedzialna lewodopa niż agoniści dopaminergiczni [30-35].

Koncepcja ciagłej stymulacji dopaminergicznej (contimuous dopaminergic stimulation - CDS) zakłada, że skuteczność leczenia farmakologicznego w odniesieniu do fluktuacji i dyskinez będzie większa, jeżeli dana forma terapii zapewni możliwie stałe pobudzenie receptorów dopaminergicznych [30-35]. Ciagła stymulacja dopaminergiczna ma być celem, a środkiem do jego osiągnięcia - odpowiedni sposób podawania leku (continuous drug delivery). Obecnie najbliższe spełnienia tego warunku są dwie tzw. terapie infuzyjne, tzn. stałe podskórne wlewy apomorfiny oraz dojelitowe wlewy lewodopy (system Duodopa). Obydwie terapie infuzyjne oraz głęboka stymulacja mózgu (deep brain stimulation - DBS) przeznaczone są dla pacjentów, u których wyczerpane zostały możliwości skutecznego prowadzenia leczenia lekami doustnymi.

O ile jednorazowe wstrzyknięcia apomorfiny moga być - zwłaszcza w świetle przedstawionej wcześniej farmakokinetyki - rozpatrywane jako forma terapii pulsacyjnej, o tyle efektywność ciagłych wlewów podskórnych może stanowić potwierdzenie słuszności koncepcji CSD. 
Spektakularnych dowodów w tym zakresie dostarczyło badanie przeprowadzone na makakach jawajskich, u których wywołano parkinsonizm poprzez podanie 1-metylo-4-fenylo-1,2,3,6-tetrahydropirydyny (MPTP). Następnie stosowano apomorfinę w postaci wstrzyknięć (terapia pulsacyjna) lub wszczepiano podskórnie implant uwalniający lek w sposób ciągły (CDS). W pierwszym przypadku u wszystkich zwierząt ciężkie dyskinezy ujawniały się po 7-10 dniach terapii, w drugim nie obserwowano ich przez 6 miesięcy leczenia, przy czym oba sposoby podawania leku pozwalały równie skutecznie kontrolować objawy zespołu parkinsonowskiego [36].

W latach 1993-2012 opublikowano wyniki 17 badań, których przedmiotem była ocena skuteczności ciągłych wlewów apomorfiny u pacjentów z zaawansowaną chorobą Parkinsona. Były to badania klasy III i IV według EFNS [37], co oznacza, że nie zostały przeprowadzone badania prospektywne $\mathrm{z}$ randomizacją i grupą kontrolną. Sytuacja apomorfiny jest pod tym względem inna niż obu terapii konkurencyjnych: dostępne są wyniki 6 badań klasy I i 4 klasy II dla DBS oraz po jednym badaniu klasy I i II dla Duodopy. Niezależnie od tej sytuacji, zgromadzone dotychczas dane na temat skuteczności wlewów podskórnych apomorfiny są wystarczająco przekonujące, aby móc ją traktować jako pełnoprawną alternatywę dla dwóch pozostałych metod leczenia [38-40].

Zarówno przed DBS, jak i obiema terapiami infuzyjnymi stawiane są te same zasadnicze cele: skrócenie łącznego dziennego czasu off $\mathrm{i}$ wydłużenie czasu on, zmniejszenie nasilenia objawów w stanie on oraz skrócenie czasu trwania i redukcja nasilenia dyskinez.

\section{Fluktuacie ruchowe}

W prawie wszystkich badaniach $\mathrm{z}$ apomorfina podawaną w sposób ciąły ocenianym parametrem był łączny czas trwania stanów off. Ulegał on skróceniu o 36-85\% [39]. Dla przykładu w badaniu prospektywnym (12 pacjentów, 6-miesięczny okres obserwacji) wykazano, że codzienne wlewy apomorfiny (średnia dawka: 75,2 mg/ dobę) pozwoliły zredukować o $38 \%$ (6,3 $\pm 2,7 \mathrm{w}$ po równaniu z 3,9 $\pm 2,1$ godz.) łączny czas off [41]. Drugie prospektywne badanie (13 chorych, czas leczenia: 12 miesięcy) potwierdziło, że apomorfina umożliwia istotne skrócenie całkowitego czasu off $(51 \%, 2,8 \pm 0,8$ w porównaniu z 1,4 \pm 0,5 godz.) [42].

Wyniki badania retrospektywnego [43], którym objęto 82 pacjentów (leczonych 19,9 \pm 16,3 miesiąca, dawka 72,00 $\pm 21,38 \mathrm{mg} /$ dobę) wykazały znamienne zmniejszenie liczby epizodów (4,6 w porównaniu z 1,4) i łącznego czasu off (6,6 w porównaniu z 1,4 godz.) [43].

Rzadziej oceniana była zmiana w zakresie stanów on . Obserwowano ich wydłużenie w ciagu dnia o 20\% [41], $29 \%$ [44] i $48 \%$ [45].

Opisywano zarówno redukcję nasilenia objawów w stanie off (wynik pełnej skali UPDRS - 68,1 w po równaniu $\mathrm{z} 44,7$ oraz jej III części - 42,3 w porównaniu $z$ 28,6) [43], jak i brak poprawy w stanie on i off (UPDRS III) $[42,45]$.

\section{Dyskinezy}

W odniesieniu do dyskinez wyniki badań są mniej jednoznaczne. Poprawę wykazano w jednym badaniu prospektywnym: o $40 \%(2,1 \pm 0,8 \mathrm{w}$ porównaniu z 1,3 $\pm 0,7$, punkt 32 skali UPDRS) skrócił się czas trwania dyskinez, a o $31 \%(2,4 \pm 1,1 \mathrm{w}$ porównaniu z 1,7 $\pm 0,8$, UPDRS 33) zredukowane zostało ich nasilenie [41]. Również w jednym badaniu retrospektywnym potwierdzono zmniejszenie intensywności dyskinez (UPDRS, 1,67 w porównaniu z 1,15) [43]. Inne badanie prospektywne nie ujawniło poprawy w zakresie dyskinez $(9,1 \pm 2,8$ w porównaniu z 9,4 $\pm 3,1$, skala AIMS) [42]. Podobne wyniki przyniosło inne badanie prospektywne [46]. W dalszej części artykułu przedstawiono wyniki kolejnej pracy, która nie wykazała poprawy w zakresie dyskinez [45].

Ważną przyczyną tych rozbieżności może być stosowanie równocześnie $z$ apomorfiną innych leków przeciwparkinsonowskich, a przede wszystkim mającej duży potencjał dyskinezotwórczy lewodopy. Zwykle po włączaniu do terapii wlewów apomorfiny zachodzi potrzeba podobnie jak w przypadku DBS - zmniejszenia dawki lewodopy. Podskórne wlewy apomorfiny jako monoterapia skuteczniej zmniejszały nasilenie dyskinez niż utrzymywanie jednoczesnego podawania leków doustnych (odpowiednio 64\% i 30\%) [44], przy czym czas oczekiwania na maksymalną poprawę w zakresie dyskinez był długi i bardzo zróżnicowany: 0,5-50 (średnia: 12,1) miesięcy [44]. W innej pracy dzięki monoterapii uzyskano 65-procentową redukcję nasilenia i zmniejszenie o $85 \%$ czasu trwania dyskinez, a średni okres od ustalenia dawki apomorfiny do uzyskania tego „optymalnego efektu antydyskinetycznego" wynosił 18 tygodni [47].

Być może ten czas jest niezbędny, aby - dzięki ciągłej stymulacji receptorów dopaminergicznych - doszło do odwrócenia zmian funkcjonalnych, jakie w jądrach podstawy zaszły pod wpływem wcześniejszej stymulacji pulsacyjnej [44]. Może to oznaczać, że okres obserwacji 
w niektórych badaniach prospektywnych jest zbyt krótki, aby efekt antydyskinetyczny zdążył się ujawnić.

\section{Dawkowanie}

Apomorfina w postaci ciągłych wlewów podskórnych stosowana jest w szerokim zakresie dawek, większość prac podaje wartości mieszczące się w przedziale od 30 do $160 \mathrm{mg} /$ dobę [41-45]. Ustalanie odpowiedniej dla pacjenta dawki leku powinno się odbywać $\mathrm{w}$ warunkach kilkudniowej hospitalizacji. Wlewy wykonywane są najczęściej przez 12 godz. Zazwyczaj - nawet po 2 latach od rozpoczęcia terapii - nie zachodzi potrzeba zwiększania dawki ustalonej na początku leczenia $[44,47,48]$.

\section{Objawy niepożq̨dane}

Długoterminowe obserwacje wykazują, że do najczęstszych objawów niepożądanych w przebiegu przewlekłego podskórnego stosowania apomorfiny należą: senność, halucynacje, hiperseksualizm, nudności i niedociśnienie ortostatyczne. Charakterystycznym i najważniejszym objawem niepożądanym są jednak zmiany skórne w postaci guzków i martwiczych owrzodzeń [47], będących objawem zapalenia tkanki podskórnej [49]. Dane na ten temat w większości pochodzą nie tyle z badań klinicznych, ile z prac oceniających przebieg długoterminowej terapii w ramach rutynowej praktyki klinicznej.

Wieloośrodkowe badanie hiszpańskie (82 pacjentów, czas trwania leczenia co najmniej 3 miesiące) wykazało obecność zmian dermatologicznych u 68\% (w tym znacznie nasilonych u 9\%) chorych [43]. Inni autorzy w grupie 64 chorych (średni czas terapii 33 miesiące) obserwowali podskórne guzki u prawie wszystkich pacjentów: u $2 / 3$ nie stwarzały one istotnych problemów, ale w $5 \%$ przypadków były przyczyną przerwania leczenia [44]. Zmiany skórne mogą się rozwinąc w różnym czasie od rozpoczęcia wlewów, u niektórych pacjentów już po kilku tygodniach [47], ale do przerwania terapii z tego powodu może dojść nawet po 48 miesiącach leczenia [46].

Guzki i owrzodzenia ustępują stopniowo po zaprzestaniu wlewów apomorfiny [50]. W leczeniu skuteczne mogą być stosowane miejscowo ultradźwięki [51]. Profilaktyka zmian skórnych polega na rotacji miejsc wkłucia. Kontrola stanu skóry i systematyczne monitorowanie ewentualnych zmian oraz ich właściwe leczenie powinny być stałym elementem opieki nad chorymi otrzymującymi przewlekle podskórne wlewy apomorfiny [52].

\section{Apomorfina, Duodopa i głęboka stymulacja mózgu}

Ponieważ te trzy metody leczenia przeznaczone są dla tej samej grupy pacjentów, decyzja dotycząca wyboru jednej z terapii powinna się opierać $z$ jednej strony na porównaniu ich efektywności, a z drugiej strony uwzględniać przeciwwskazania i profil działań niepożąanych.

Tylko w jednej pracy [53] podjęto próbę bezpośredniego porównania skuteczności obu terapii infuzyjnych i DBS (10 pacjentów w każdej grupie). Pacjenci otrzymujący apomorfinę znamiennie rzadziej, w porównaniu z leczonymi DBS i Duodopą, znajdowali się w stanie on, dominował częściowy stan off. W zakresie funkcji motorycznych apomorfina była istotnie mniej skuteczna niż DBS (nie było znamiennych różnic w porównaniu z Duodopą). Zaskakująco, dyskinezy stanowiły większy problem u pacjentów otrzymujących dojelitowe wlewy lewodopy niż u chorych z DBS lub leczonych apomorfiną [53].

Porównanie skuteczności podskórnych wlewów apomorfiny i stymulacji jądra niskowzgórzowego (DBSSTN) było celem dwóch prac $[42,46]$ oceniających wpływ obu terapii na funkcje poznawcze. W pierwszej zakładano 5-letni okres obserwacji, który osiągnęli wszyscy (13) pacjenci z DBS i tylko 2 z 12 leczonych apomorfiną. Terapia DBS-STN pozwalała na skuteczniejszą kontrolę objawów ruchowych. Jednak przeprowadzona po roku oraz ostatnia (średnio po 40 miesiącach) ocena stanu pacjentów tylko u chorych leczonych DBS ujawniła znamienne pogorszenie, wyjściowo prawidłowych, wyników Inwentarza Neuropsychiatrycznego (w następstwie wystąpienia apatii u 4 chorych) oraz fluencji słownej $[42,46]$.

Przeciwwskazania do DBS w chorobie Parkinsona są stosunkowo liczne. Obejmują wszystkie stopnie zaawansowania zespołu otępiennego, zespół dysregulacji dopaminergicznej, zaburzenia kontroli impulsów, przebyte poważne epizody psychotyczne niemające związku ze stosowaniem leków dopaminergicznych, znacznie nasilone zaburzenia nastroju, przebyte epizody dużej depresji, zwłaszcza z myślami samobójczymi. Drugą grupę stanowią przeciwwskazania do samego zabiegu: nasilone zmiany zanikowe mózgu, zmiany ogniskowe (w tym naczyniowopochodne) oraz zaburzenia krzepnięcia krwi i stosowanie leków przeciwzakrzepowych [39,54-56]. Chorzy z zaburzeniami mowy i połykania, które mogą ulec nasileniu po zastosowaniu DBS, nie są dobrymi kandydatami do DBS [39]. 
Brakuje wiarygodnych danych mówiących, jaki procent pacjentów, którzy ze względu na stopień zaawansowania choroby są potencjalnymi kandydatami do DBS, nie może być leczonych w ten sposób z powodu występowania dyskwalifikujących przeciwwskazań. $\mathrm{Z}$ zestawienia materiału obejmującego 82 pacjentów z 35 ośrodków hiszpańskich wynika, że 52\% nie mogło być zakwalifikowanych do DBS, a dodatkowo $9 \%$ stanowili chorzy, u których zastosowanie DBS zakończyło się niepowodzeniem [43]. Można więc przyjąć, że liczba pacjentów wymagających zastosowania jednej z terapii infuzyjnych jest zbliżona do liczby chorych, którzy mogliby być leczeni z zastosowaniem DBS.

W ostatnio opublikowanej pracy [45] przedstawiono wyniki prospektywnego badania oceniającego efekty 12 -miesięcznej terapii ciągłymi wlewami apomorfiny u 23 pacjentów. Głęboka stymulacja mózgu u tych osób nie mogła być zastosowana ze względu na: 1) upośledzenie funkcji poznawczych (wynik Mattis Dementia Rating Scale $\leq 130)$ i/lub 2) zespół dysfunkcji wykonawczej (upośledzenie w zakresie co najmniej 3 funkcji), i/lub 3) obecność niereagujących na lewodopę ruchowych objawów osiowych (dyzartria, zamrożenie chodu i upadki; wynik „podskali osiowej” III części UPDRS $\geq 3$ ). Satysfakcja pacjentów oceniana za pomoca skali VAS wyniosła $52,8 \pm 16,4$ (25-75). Łączny czas stanu off skrócił się o $36 \%$, a stanu on wydłużył o $48 \%$ (różnice znamienne statystycznie). Nasilenie objawów w stanach off i on nie uległo zmianie. Nie stwierdzono skrócenia czasu z dyskinezami, pomimo zredukowania dawki lewodopy o $26 \%$. Nie odnotowano pogorszenia w zakresie funkcji poznawczych ani osiowych objawów motorycznych. W pracy znajduje potwierdzenie pogląd, że podskórne wlewy apomorfiny powinny być rozpatrywane jako alternatywa dla DBS w przypadku przeciwwskazań dla tej ostatniej, z za strzeżeniem, że lepszymi kandydatami do tej terapii infuzyjnej są chorzy z niewielkim nasileniem dyskinez [45].

Jak już wspomniano wcześniej, efektywność leczenia ciągłymi wlewami podskórnymi apomorfiny nie była weryfikowana prospektywnymi badaniami z randomizacją i grupą kontrolną. $Z$ drugiej strony ta forma terapii stosowana była znacznie wcześniej niż DBS lub dojelitowe wlewy lewodopy i m.in. to wieloletnie doświadczenie wyniesione z praktyki powoduje, że jest brana pod uwagę jako alternatywa dla DBS i Duodopy. To, która metoda leczenia zostanie zastosowana u pacjenta - jeżeli wszystkie są dostępne - zależy od kilku czynników. Głęboka stymulacja mózgu jest procedurą najbardziej inwazyjną, ale niewątpliwie zapewnia choremu naj- większy stopień niezależności w życiu codziennym. W przypadku terapii infuzyjnych należy przyjąć zasadę, że pacjent na co dzień ma zapewnioną pomoc opiekuna, który potrafi obsługiwać pompę podającą lek. Tylko co czwarty pacjent jest $\mathrm{w}$ stanie w pełni samodzielnie wykonywać wszystkie czynności związane z przygotowaniem i podłączeniem pompy, większość pacjentów nie może - ze względu na niesprawność ruchową załadować strzykawki do pompy i wkłuć igły [44].

Przy ostatecznym wyborze metody leczenia powinny być również brane pod uwagę preferencje pacjenta $[38,39,55,56]$. W przypadku co piątego pacjenta leczonego apomorfiną w Hiszpanii wybór tej metody leczenia był decyzją samego chorego [43]. Chorzy mogą odbierać wlewy apomorfiny jako leczenie najmniej inwazyjne, z którego w każdej chwili można zrezygnować.

Na uwadze należy mieć także wysoki koszt mający wpływ na dostępność DBS i terapii infuzyjnych. Obecnie najtańsze jest leczenie z zastosowaniem DBS, a najbardziej kosztowne są dojelitowe wlewy lewodopy.

Leczenie pacjentów z chorobą Parkinsona wymagających zastosowania DBS lub jednej z terapii infuzyjnych powinno być prowadzone w wyspecjalizowanych ośrodkach referencyjnych [55]. Jest to optymalne rozwiązanie, stosowane $\mathrm{z}$ powodzeniem $\mathrm{w}$ innych krajach. Ośrodki takie zapewniają pacjentom opiekę wielospecjalistycznego zespołu, w skład którego wchodzi neurolog, neurochirurg, psycholog i odpowiednio przygotowana pielęgniarka [57], która odgrywa ważną rolę w opiece nad pacjentami poddanymi jednej z terapii infuzyjnych.

\section{Oświadczenie}

Autor zgłasza brak konfliktu interesów.

\section{Piśmiennictwo}

1. Lees A., Turner K. Apomorphine for Parkinson's disease. Pract Neurol 2002; 2: 280-286.

2. Menon R., Stacy M. Apomorphine in the treatment of Parkinson's disease. Expert Opin Pharmacother 2007; 8: 1941-1950.

3. Harder S., Baas H., Demisch L., et al. Dose response and concentration response relationship of apomorphine in patients with Parkinson's disease and end-of-dose akinesia. Int J Clin Pharmacol Ther 1998; 36: 35 5-362.

4. Hofstee D.J., Neef C., van Laar T., et al. Pharmacokinetics of apomorphine in Parkinson's disease: plasma and cerebrospinal fluid levels in relation to motor responses. Clin Neuropharmacol 1994; 17: 45-52. 
5. Neef C., van Laar T. Pharmacokinetic-pharmacodynamic relationships of apomorphine in patients with Parkinson's disease. Clin Pharmacokinet 1999; 37: 257-271.

6. Gunzler S.A. Apomorphine in the treatment of Parkinson disease and other movement disorders. Expert Opin Pharmacother 2009; 10: 1027-1038.

7. Esteban Muñoz J., Martí M.J., Marín C., et al. Long-term treatment with intermittent intranasal or subcutaneous apomorphine in patients with levodopa-related motor fluctuations. Clin Neuropharmacol 1997; 20: 245-252.

8. Dewey R.B. Jr, Maraganore D.M., Ahlskog J.E., et al. Intranasal apomorphine rescue therapy for parkinsonian "off" periods. Clin Neuropharmacol 1996; 19: 193-201.

9. Dewey R.B. Jr, Maraganore D.M., Ahlskog J.E., et al. A double-blind, placebo-controlled study of intranasal apomorphine spray as a rescue agent for off-states in Parkinson's disease. Mor Disord 1998; 13: 782-787.

10. Montastruc J.L., Rascol O., Senard J.M., et al. Sublingual apomorphine in Parkinson's disease: a clinical and pharmacokinetic study. Clin Neuropharmacol 1991; 14: 432-437.

11. Hughes A.J., Webster R., Boningdon M., et al. Sublingual apomorphine in the treatment of Parkinson's disease complicated by motor fluctuations. Clin Neuropharmacol 1991; 14: 556-561.

12. Ondo W., Hunter C., Almaguer M., et al. A novel sublingual apomorphine treatment for patients with fluctuating Parkinson's disease. Mov Disord 1999; 14: 664-668.

13. Hughes A.J., Bishop S., Lees A., et al. Rectal apomorphine in Parkinson's disease. Lancet 1991; 337: 118.

14. Van Laar T., Jansen E.N., Neef C., et al. Pharmacokinetics and clinical efficacy in patients with Parkinson's disease: a study of five different suppositories. Mov Disord 1995; 10: 433-439.

15. Grosset K.A., Malek N., Morgan F., et al. Phase IIa randomized double-blind, placebo-controlled study of inhaled apomorphine as acute challenge for rescuing 'off periods in patients with established Parkinson's disease. Eur J Neurol 2013. DOI: 10.1111/ene.12091.

16. Dewey R.B. Jr, Hutton J.T., LeWitt P.A., et al. A randomized, double-blind, placebo-controlled trial of subcutaneously injected apomorphine for parkinsonian off-state events. Arch Neurol 2001; 58: 1385-1392.

17. Stacy M., Silver D. Apomorphine for the acute treatment of "off" episodes in Parkinson's disease. Parkinsonism Relat Disord 2008; 14: 85-92.

18. Pfeiffer R.F., Gutmann L., Hull K.L. Jr., et al. Continued efficacy and safety of subcutaneous apomorphine in patients with advanced Parkinson's disease. Parkinsonism Relat Disord 2007; 13: 93-100.

19. Pahwa R., Koller W.C., Trosch R.M., et al. Subcutaneous apomorphine in patients with advanced Parkinson's disease: a doseescalation study with randomized, double-blind, placebo-controlled crossover evaluation of a single dose. J Neurol Sci 2007; 258: 137-143.

20. Ostergaard L., Werdelin L., Odin P., et al. Pen injected apomorphine against off phenomena in late Parkinson's disease: a double blind, placebo controlled study. J Neurol Neurosurg Psychiatry 1995; 58: 681-687.
21. Deffond D., Durif F., Tournilhac M. Apomorphine in treatment of Parkinson's disease: comparison between subcutaneous and sublingual routes. J Neurol Neurosurg Psychiatry 1993; 56: 101-103.

22. Frankel J.P., Lees A.J., Kempster P.A., et al. Subcutaneous apomorphine in the treatment of Parkinson's disease. J Neurol Neurosurg Psychiatry 1990; 53: 96-101.

23. Pietz K., Hagell P., Odin P. Subcutaneous apomorphine in late stage Parkinson's disease: a long term follow up. $J$ Neurol Neurosurg Psychiatry 1998; 65: 709-716.

24. Poewe W., Kleedorfer B., Gerstenbrand F., et al. Subcutaneous apomorphine in Parkinson's disease. Lancet 1988; 1: 943.

25. Stibe C.M., Lees A.J., Kempster P.A., et al. Subcutaneous apomorphine in parkinsonian on-off oscillations. Lancet 1988; 1 : 403-406.

26. Verhagen M.L., Locatelli E.R., Bravi D., et al. Apomorphine responses in Parkinson's disease and pathogenesis of motor complications. Neurology 1997; 48: 369-372.

27. Stacy M. Apomorphine: North American clinical experience. Neurology 2004; 62 (6 Suppl 4): S18-S21.

28. Ondo W.G., Hunter C., Ferrara J.M., et al. Apomorphine injections: predictors of initial common adverse events and long term tolerability. Parkinsonism Relat Disord 2012; 18: 619-622.

29. Chaudhuri K.R., Clough C., Blockley A. The use of apomorphine in Parkinson's disease. $1^{\text {st }}$ ed. King's College Hospital NHS Trust, 2001

30. Jenner P. Avoidance of dyskinesia: preclinical evidence for continuous dopaminergic stimulation. Neurology 2004; 62 (1 Suppl 1): S47-S55.

31. Nutt J.G., Obeso J.A., Stocchi F. Continuous dopamine-receptor stimulation in advanced Parkinson's disease. Trends Neurosci 2000; 23 (10 Suppl): S109-S115.

32. Obesso J.A., Rodriguez-Oroz M., Marin C., et al. The origin of motor fluctuations in Parkinson's disease. Importance of dopaminergic innervations and basal ganglia circuits. Neurology 2004; 62 (Suppl 1): S17-S30.

33. Olanow C.W., Schapira A.H.V., Rascol O. Continuous dopamine-receptor stimulation in early Parkinson's disease. Trends Neurosci 2000; 23 (10 Suppl): S117-S126.

34. Olanow C.W., Obeso J.A., Stocchi F. Continuous dopaminereceptor treatment of Parkinson's disease: scientific rationale and clinical implications. Lancet Neurol 2006; 5: 677-687.

35. Stocchi F. The hypothesis of the genesis of motor complications and continuous dopaminergic stimulation in the treatment of Parkinson's disease. Parkinsomism Relat Disord 2009; 15 (Suppl 1): S9-S15.

36. Bibbiani F., Costantini L.C., Patel R., et al. Continuous dopaminergic stimulation reduces risk of motor complications in parkinsonian primates. Exp Neurol 2005; 192: 73-78.

37. Brainin M., Barnes M., Baron J.-C., et al. Guidance for the preparation of neurological management guidelines by EFNS scientific task forces - revised recommendations. Eur J Neurol 2004; 11: 577-581.

38. Clarke C.E., Worth P., Grosset D., et al. Systematic review of apomorphine infusion, levodopa infusion and deep brain stimulation in advanced Parkinson's disease. Parkinsonism Relat Disord 2009; 15: 728-741. 
39. Volkmann J., Albanese A., Antonini A., et al. Selecting deep brain stimulation or infusion therapies in advanced Parkinson's disease: an evidence-based review. J Neurol 2013. DOI: 10.1007/s00415012-6798-6.

40. Antonini A., Odin P. Pros and cons of apomorphine and L-dopa continuous infusion in advanced Parkinson's disease. Parkinsonism Relat Disord 2009; 15S: S97-S100.

41. Katzenschlager R., Hughes A., Evans A., et al. Continuous subcutaneous apomorphine therapy improves dyskinesias in Parkinson's disease: a prospective study using single-dose challenges. Mov Disord 2005; 20: 151-157.

42. De Gaspari D., Siri C., Landi A., et al. Clinical and neuropsychological follow up at 12 months in patients with complicated Parkinson's disease treated with subcutaneous apomorphine infusion or deep brain stimulation of the subthalamic nucleus. J Neurol Neurosurg Psychiatry 2006; 77: 450-453.

43. García Ruiz P.J., Sesar Ignacio A., Ares Pensado B., et al. Efficacy of long-term continuous apomorphine infusion in advanced Parkinson's disease with motor fluctuations: a multicenter study Mov Disord 2008; 23: 1130-1136.

44. Manson A.J., Turner K., Lees A.J. Apomorphine monotherapy in the treatment of refractory motor complications of Parkinson's disease: long-term follow-up study of 64 patients. Mov Disord 2002; 17: 1235-1241.

45. Drapier S., Gillioz A.-S., Leray E., et al. Apomorphine infusion in advanced Parkinson's patients with subthalamic stimulation contraindications. Parkinsonism Relat Disord 2012; 18: 40-44.

46. Antonini A., Isaias I.U., Rodolfi G., et al. A 5-year prospective assessment of advanced Parkinson disease patients treated with subcutaneous apomorphine infusion or deep brain stimulation. $J$ Neurol 2011; 258: 579-585.

47. Colzi A., Turner K., Lees A.J. Continuous subcutaneous waking day apomorphine in the long term treatment of levodopa induced interdose dyskinesias in Parkinson's disease. J Neurol Neurosurg Psychiatry 1998; 64: 573-576.

48. Kanovský P., Kubová D., Bares M., et al. Levodopa-induced dyskinesias and continuous subcutaneous infusions of apomorphine: results of a two-year, prospective follow-up. Mov Disord 2002; 17: 188-191.

49. Acland K.M., Churchyard A., Fletcher C.L., et al. Panniculitis in association with apomorphine infusion. Br J Dermatol 1998; 138: 480-482.

50. Ganesalingam J., Bain P. Apomorphine-induced necrotic ulcers. Mov Disord 2011; 26: 2182.

51. Poltawski L., Edwards H., Todd A., et al. Ultrasound treatment of cutaneous side-effects of infused apomorphine: a randomized controlled pilot study. Mov Disord 2009; 24: 115-118.

52. Todd A., James C.A. Apomorphine nodules in Parkinson's disease: best practice considerations. Br J Community Nurs 2008; 13: 457-463.

53. Elia A.E., Dollenz C., Soliveri P., et al. Motor features and response to oral levodopa in patients with Parkinson's disease under continuous dopaminergic infusion or deep brain stimulation. Eur J Neurol 2012; 19: 76-83.

54. Benabid A.L., Chabardes S., Mitrofanis J., et al. Deep brain stimulation of the subthalamic nucleus for the treatment of Parkinson's disease. Lancet Neurol 2009; 8: 67-81.
55. Carron R., Fraix V., Maineri C., et al. High frequency deep brain stimulation of the subthalamic nucleus versus continuous subcutaneous apomorphine infusion therapy: a review. $J$ Neural Transm 2011; 118: 915-924.

56. Hilker R., Antonini A., Odin P. What is the best treatment for fluctuating Parkinson's disease: continuous drug delivery or deep brain stimulation of the subthalamic nucleus? J Neural Transm 2011; 118: 907-914.

57. Bowron A. Practical considerations in the use of apomorphine injectable. Neurology 2004; 62 (6 Suppl 4): S32-S36. 